\title{
Towards a Contingency Theory of Control in Information Systems Development Projects
}

\author{
Ranjit Tinaikar \\ Paulo R. Flor
}

University of Pittsburgh

259 Mervis Hall, Joseph M. Katz Graduate School of Business

Pittsburgh, PA 15260, USA

Phone \#: (412) 648-1639, FAX \#: (412) 648-1693

E-mail: RXTST(a)vms.cis.pilt.edı

PRFST3+(a)pilt.edu

Palavras-chave : sistemas de informação, teoria contigencial, projeto de sistemas, DSI

Keywords : information systems, contigency theory, systems design, ISD

\section{RESUMO}

O principal objetivo deste trabalho é o de fomecer uma teoria contigencial de controle para a informatização do gerenciamento de projetos de desenvolvimento de sistemas de informação (DSI). Controle é caraterizado por niveis de formalidade. O modelo teórico traz conjuntamente a construção central para controle, contexto e consequências. Seis lipos de mecanismos de controle, que podem ser usados en várias combinações, são identificados e classilicados. O contexto é arranjado hierarquicamente em très niveis e fornece os virios fittores contigenciais que podem afetar o controle de projetos DSI. Finalmente, as consequencias são divididas, ainda mais, em très perspectivas, cada uma fomecendo um novo angulo para estudar as saidas de projetos DSI. As amplas propostas unindo as três construções deve fomecer uma base para futuras pesquisals en gerenciamento de projetos DSI.

\footnotetext{
ABSTRACT

The main objective of this article is to provide a contingency theory of control for informing the project management of information systems development (ISD). Control is characterized by levels of formality. The theoretical framework provides a propositional inventory by bringing together the three central constructs of control, context and consequence. Six types of control mechanisms which can be used in various mites are identified and classified under an informalfformal continum. The contert is hierarchically arranged into three levels and provides the various contingency factors which may affect the control of ISD projects. Finally, the consequences are further divided into three perspectives, each of which provides a new angle to study the outcome of ISD projects. The broad propositions linking the three constructs should provide the basis for future research on the management of $I S D$ projects.
} 


\section{Introduction}

Management of information systems development (ISD) projects has been an enduring concern wilh both academicians and practitioners for a long time. During this time a number of solutions have been provided to increase the project's chances of success. These solutions have ranged from ad hoc critical success factors and risk management heuristics to propositions well guided in theory.

In spitc of these efforts, organizations of today are still faced with significant capacity problems (BENJAMIN, 1982 , KEMERER, 1989, KOLODZIEJ, 1986), poor productivity (JONES, 1987), if not outright failure (KEMERER \& SOSA, 1990). Hence, continued research leading to better understanding of factors causing poor performance and the steps that may be taken to improve them is clearly warranted.

A number of theoretical approaches to the study of ISD have been adopted by IS rescarchers. They can vary from the perspective of influence in the user-analyst relationship (EDSTROM, 1977, ROBEY \& FARROW. 1982), to the angle of effective communication (BOLAND, 1978, DE BRABANDER \& THIERS, 1984), and to the vicus of project management as conflict resolution strategy development (HIRSCHHEIM et al, 1987, ELAM \& WALZ, 1988). Each of thesc perspectives is valid and provides an important insight into the development effort involved in the building of an IS theory. This study is another attempt in this direction. Our main objective here is to present a theoretical approach to ISD which explains the project management process on the basis of a systematically tested network of constructs (a nomological network). In order to do this we adopt a control theory perspective which views the project management outcomes as a control phenomenon that is contingent on environmental conditions.

Control, context and consequences and are the three important dimensions of our framework. This framework will be used as a basis for bringing logether the various issues, concepts and cmpirical findings in the IS literature. Considering the breadth of the knowledge body being addressed, the nature of the task attempted in this paper may be considered quite ambitious. However, the objective of this paper is not to provide an in depth detailed analysis of ISD but to provide a broad framework which could be used to generate certain research propositions. Through this effort we hope to create the foundation for the development of a contingency based control theory in ISD.

The next section will deal with the dimension of control. Applying contemporay management control theory, we will argue that ISD projects are managed through a mix of controlling mechanisms that vary according to their level of formality. The following section will introduce the dimension of environmental context. In this paper, environment will be hicrarchically divided into project, organizational and cxternal convironments. Each environment has been characterized in the literature in various 
different ways and this will be the subject of discussion. Next, we will deal with the consequences dimension of the framework. Consequences of ISD projects have been studied primarily under the banner of IS performance (DELONE \& MCLEAN, 1992, MASON, 1978). Our taxonomy will address the consequences of ISD projects from the perspective of the project group and the organization, as well as the individual team members. Finally, we will discuss the implications of the above three dimensions within the contingency framcwork and gencratc rescarch propositions which lead us towards a contingency theory of ISD project control management.

\section{The Control Dimension}

A number of definitions of control have been provided. Some such as Flamholtz et al (1985) view control in the narrow sense as a cybernetic system. Others such as Jaworski (1988) and Merchant (1985) take a more holistic view of control. For the purpose of this paper we shall sec control as "..having one basic function: to help ensure the proper behaviors of people in the organization. These behaviors should be consistent with the organization's strategy if one cxists, which, in turn should have been selected as the best path taken towards achievement of the organization's objectives" (MERCHANT, 1985, p.4).

Such a definition of control provides us a way to accommodate the cxistence of both informal and formal controlling forces in various mixes. It also allows us to view control as being cxerted by either the management, workers or any other stakeholder.

The issue of formality has been widely discussed in control literature. Weber is often associated with the formal view of control. This view sees control as well defined standard operating procedures which regulates employec bchavior. Woodward (1970) views control as a cybenetic process which tries to control by measuring outcome of the task. Ouchi (1977), Ouchi and Maguirc (1975) and Eiscnhardt (1985) take a broader view where control implies monitoring and cvaluating both the outcome and behavior. Jaworski (1988) proposed a more holistic approach to control which subsumes all of the above. However, while he assumes a formal/informal dichotomy, we view the formality of a control mechanism along a continum which ranges from purely informal at one cxtreme to purely formal at the other. Below we discuss the six different lypes of control mechanisms which can cocxist in various mixes in an organization to make the control system range from purcly formal to purely informal.

\section{- Formal Control}

Formal control of any task within the organization can be performed in threc ways: input control, process control and output control. "Input controls are measurable actions taken by the firm prior to the implementation of the activity... Process control is exercised when the firm attempts to influence the means to achicre 
the desired ends... Output control is exercised when performance standards are sel, monitored and results evaluated" (JAWORSKI, 1988, p. 26). While these definitions of control apply to the firm level, we will describe them at the team level which is our unit of analysis.

(i) Input Control: The inputs to the activity can be controlled through the management of the various resources available to the project. These resources may be broadly divided into two types: human and non-human resources. The nature of the human resources made available to the project can go a long way in influcncing its final outcomc. It deals not only with the quantity of staff allocated but also its quality. Staffing represents the former concern and expertise the latter. Staffing deals with providing the right amount of people at the right lime and ensuring that staff turnover is low so as to maintain continuity of the project. On the other hand, the issue of expertise is concerned with the knowledge body made available to the project through people with the right kind of expertise (MCCOMB \& SMITH, 1991).

A varicty of non-human resources are also required for project completion. These include capital, hardware and project management tools and techniques. These can be obtained either from within the organization or from cxtcrnal sources. In the former case, one achieves input control through setting the system objectives. In the latter case, input control is achieved through a bid strategy which lays down the critcrion for selecting among the various cxternal bidders for the project (MCCOMB \& SMITH, 1991). It should be noted here that the bid strategy can also be used to perform human resource input control by acquiring human expertise from an external body.

(ii) Process Control: Process control may be achieved through either behavioral or structural means (JAWORSKI, 1988). The behavioral process control is used for controlling the human resource while structure may be used for non-human as well as human resources. Behavior may be controlled through a reward punishment systcm based on standard opcrating procedures laid down for the group. On the other hand, structure can also serve as a mcans for achieving process control. Mantei (1981) claimed two prominent control structures in ISD -- the chief programmer team proposed by Mills (1971) and the egoless programming tcam proposed by Weinberg (1971). Henderson and Lee (1992) interpreted these two to represent a purely hicrarclical and a purely decentralized structure.

(iii) Otuput Control: Output control is said to take place when the controlling mechanism is based purely on the outcome of the process, without specifying the process itself. This can be done by evaluating performance against a set budget or a schedulc. It should be noted that the budget and schedules may be used as both input and output controls. However, in the former they are used for controlling resource allocations and in the latter they are used for cvaluating the use of these resources. 


\section{- Informal Control:}

"Informal controls are the unwritten, typically worker-based mechanisms that influence individual and group behavior" (JAWORSKI, 1988, p. 27). Three levels of aggregation can be used to understand control within a project team. While self control is exerted by the team member, social control is exerted by the team and the IS function, and cultural control is cxerted by the organization in which the team operates.

(i) Self Control: "Tcam-member self control is defined as the extent to which an individual cxercises frecdom or autonomy to determine both what actions are required and how to cxecutc these activitics" (HENDERSON \& LEE, 1992, p. 760). Sclf control may be used by the team members when the group cannot adequately measure behavioral performance or standardize transformation process. However self control should not be cquated to no control (LAWLER, 1976). Henderson and Lee (1992), Weinberg (1971) and Bailyn (1984) have shown that the performance of technically oriented tcams in fact improves with increased self control.

(ii) Social Control: "Social control can be defined more formally as the prevailing social perspectives and palterns of interpersonal interactions within subgroups in the firm." (JAWORSKI, 1988, p. 27). Social control has been defined in a number of ways by different aluthors -- clan (OUCHI. 1979), small group (DALTON, 1971), professional control (WATERHOUSE \& TIESSEN, 1978). In an ISD project tcam. social control may play an important rolc in influencing the process. For example, the social norm may decide the kind of software devclopment methodology to be used. The choice of the methodology is thus not made after a rational analysis but on the basis of a generally accepted norm.

(iii) Cultural Control: While social control is due to informal controlling forces at the small group level, cultural control occurs at a higher level of aggregation -division or firm. "..Culture is defined as the broader values and nomative patterns that guide worker bchavior within an entire organization" (OUCHI, 1979). The project tcam has to work in a larger organizational context and the forces of control which apply to the wholc organization also apply to the project tcam. For example, an organizational ideology which cmphasizes customer satisfaction will influence the projecl team in focusing on uscr satisfaction as opposed to other technical measures of performance.

\section{The Context Dimension}

The environmental context can be broadly classified as project or internal environment, organizational environment and external environment. The three levels are not completely independent of cach other. Project cnvironment may be influcenced by the organization in which it operates. The organizational conviroument may in tum be detemined by the external environment. This hicrarchical organization of the context dimension only serves as a tool in 
understanding the various environmental attributes.

\section{- Internal Environment:}

The intemal environment consists of clements within the project team's jurisdiction. It has a role in detcrmining the type of controls that crolves and in moderating the effects of the control system in usc. The internal enviromment basically deals with the characteristics of the task being performed in the project. Prediclability or measurability of the task is onc important characteristic. Ouchi (1979) suggested that tasks which are casicr to measure tend 10 make greater use of output controls. March and Simon (1958) proposed that task unpredictability largely determines what type of control is appropriatc. This unpredictability/uncertainty characteristic should be higher in projects dealing with newer IS applications. For example, projects concemed with developing a payroll system would be more predictable and certain than onc attcmpting to build an clectronic data interchange (EDI) systcm.

Similarly, the scope of the project have also becn known to affect project performance (LOUIS, 1992). Scope deals with issucs of complexity of the project. Thus uncertainty and complexity are the two characteristics of the project cnvironment. It is the that uncertainty and complcxity are not completely independent. However, for our purpose, we differentiatc on the basis that uncertainty dcals with the predictability of the task while complexity deals with its size or scope.

\section{- Organizational Environment:}

A number of organizational enviromment attributes have been identified as affecting the ISD process in an organization. The IS literature has characterized the organizational cnviromment in a number of ways. These include the size of organizations (CARTER, 1984, KLATZKY, 1970), the interdependence between IS and the rest of the organization (LUCAS, 1986, IVES \& LEARMONTH, 1984, VITALE et al. 1986) and nature of task performed by the IS function (HAREL \& MCLEAN, 1985, LUCAS, 1975). Control theory supports all the above and adds another one -- the financial status of the organization (JAWORSKI, 1988). In summary, the organizational environment of the project is characterized by size of the IS function, its linkage to the rest of the organization, the nature of its task and the financial status of the organization.

\section{- External Environment:}

This concerns with that part of the cnvironment which lies outside the boundaries of the organization for which the IS is being developed. This includes the opcrating cnviromment which consists of the suppliers, customers and competitors as well as the macro environment, which consists of political and legal issues. Uncertainty is one of the most important characteristic of this cnvironment. Envirommental uncertainty has becn conceptualized and operationalized in a number of ways. In this article, it is taken in its broadest sense which subsumes both the 
static (predictability, structuredness) as wcll as the dynamic (volatility, dynamism, stability) notions of uncertainty.

\section{The Consequences Dimension}

A number of taxonomies have been developed to study the consequences of IS projects (DELONE \& MCLEAN, 1992, IVES \& OLSON, 1984, ZMUD, 1979). Howcver, all of them focus on the issuc of IS success. IS success has been inteppreted in many different ways and in its broadest sense could cover both the teclmical (project group/producers) and organizational (user/stakeholder group) conscquences of an information system. However, it does not cover the consequences of the project for the individual project members. Our taxonomy of consequences of ISD projects also covers this latter consequence and is thus broader than the oncs provided earlicr. It uses a three-tier approach to analyzing the consequences of ISD projects. The three ticrs are: the individual project team member, the producer group and the organization (user/stakeholders).

\section{- Individual Team Member Consequences:}

The individual member consequences have been studied in a varicty of studies in psychology and control theory. For the purpose of this paper we shall use the typology provided by Jaworski (1988). Hc identifics four broad areas of individual level conscquences. "Individual consequences call be psychological (job tension). rolc-related (conflict, ambiguity, overload), bchavioral (functional and dysfunctional), and performance related" (JAWORSKI, 1988, p. 28).

Each of the above consequences is important for the successful completion of a project. Role conflict between users and devclopers has becn widely studied in the IS litcrature (ELAM \& WALZ, 1988, HIRSCHHEIM et al, 1987). However, intra project role conflict between team members (for cxample, requirement analysts and tcchnicians) have not received the attention it deserves. The effect of managerial cont ro I on project team members remains a sadly understudicd area.

\section{- Producer Team Member Consequences:}

At the project group level, the consequences will be from the producers perspective. The producer will be concerned with the technical quality of his product and the process of production (MASON, 1978). Shannon and Weaver (1949) classified Mason's production/product lypology of IS performance measures as technical and scmantic Icvels. DeLonc and McLcan (1992) use system quality and information quality to explain the same two concepts. For the purpose of this paperwe shall draw upon the above classification schemes in order to propose our own.

All of the above classifications refer to the information product and to the information system which produces it. Wc propose onc more dimension -- the production process of the ISD project. These three dimensions will be defined as follows: Prodict quality chooses "to study 
the information product characteristics such as accuracy, meaningfulness, and timclincss" (DELONE \& MCLEAN, 1992, p.62). System quality focuscs on "the desired characteristics of the information systems itself which produces the information" (DELONE \& MCLEAN, 1992, p. 62). Finally, process quality as a measure of IS performance refers to the desired characteristics of the ISD process which produces the information system.

A number of measures of both the information product and the information system have been proposed or developed (SWANSON, 1974, EMERY, 1971). Similarly, the quality of the product of the IS has also becn measured as an indicator of IS performance. These measures primarily deal with the quality of the output reports of the system. This quality has been measured in terms of perceived importance/usableness (LARCKER \& LESSIG, 1980), accuracy, rcliability, timcliness, relcvance, currency, ctc. (BAILEY \& PEARSON 1983, AHITUV 1980, MUNRO \& DAVIS. 1977).

Process productivily is also an important issuc in software development. Many of the ISD projects today are still plagued by the problem of poor productivity (JONES, 1987). A number of heuristics have been suggested in contemporary literature to improve the productivity. The measures of IS productivity have ranged from objective measures such as number of lines of code, number of errors to subjective measures which view productivity as a ralio of the costs upon benefits. A number of firms have even launched organization wide metrics programs in the hope of improving productivity (GRADY \& CASWELL, 1987). The framework proposed by Basili (1984) reflects a holistic approach to measuring productivity which incorporatcs both subjective and objective measures.

\section{- Organizational/User/Stakeholder Consequences:}

The third level of analysis consists of the individual user, stakcholder groups and the organization as a whole. This tier of consequences includes all organizational members, cxcluding the producers, who use the system or are affected by its use. These consequences have been broadly classified by Shannon and Weaver (1949) as the effect of the information on the recipient.

The lypology provided by DeLone and McLcan (1992) comes closest to our typology of user, stakcholder and organizational consequences. They provide four types of measures of IS performance from the non-produccr's perspective. In our typology the user consequences refer to the effect of the IS on the individual decision makers in the organizations who use or are affecied by the use of the IS (c.g., a manager responsible for the IS function). DeLone and McLcan call this the individual impact. The stakeholder consequences refer to the impact of the IS at the group Icvel. This includes all those groups who use or are affected by the usc of the IS (c.g., managers, workers, owners, sharcholders, elc.). DeLone and McLean refer to this issuc under the bamners of system use and user satisfaction. Organizational consequences 
of IS are concerned with the effect of the IS on organizational performance. DeLone and McLean capture this issuc under organizational impact.

\section{Research Implications}

This scction will discuss the relationships between the various dimensions described above so as to provide cerlain research propositions which could lead towards a theory of ISD project management. These propositions are based on compirical findings and conceptual discussions in the field of management control, social science and information systems literature. This section will provide broad, generalized propositions which are presented in the hope that empirical rescarch may lead 10 more refined propositions. The following figure porvides a graphical description of our model.

The controlling mechanisms used in the projecl can be viewed as being determined by the cnviromment. As described carlier, contert can be divided into three lcvels: project, organizational and cxternal cnvironments. A number of contingency studics have been provided in the IS litcrature (WEILL \& OLSON, 1989) to cxplain the influcnce of project environmental characteristics on the choice of controlling mechanisms. Burns and Demis (1985) have provided a contingency framework which links project uncertainty and complexity to the choice of devclopment methodology used. Louadi et al (1991) have used this ramework in conjunction with the Gorry and Scolt-Morton (1971) typology on IS to

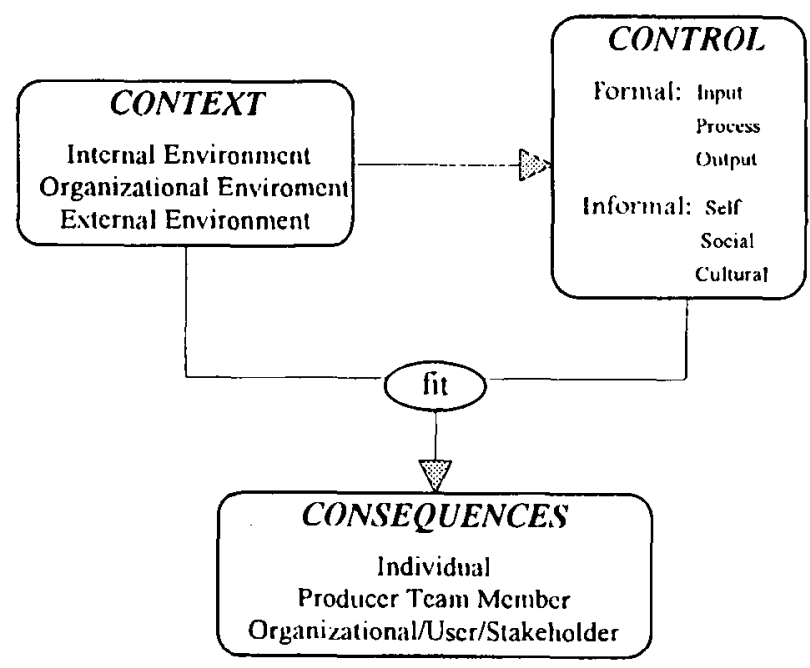

Figure 1 - Contingency Model of Control in ISD Projects. 
provide a new contingency framework which explains the formal control process uscd as a function of application lype and project characteristics. However it should be noted that most contingency frameworks in IS concentrate on the relation between cnvironment and formal control mechanisms. We also need to look at the informal controls. Henderson and Lec (1992) discuss informal controls but do not link this to environmental variables.

Control theory assents that no single system of control evolves in all organizations. Environments with greater degrec of uncertainty and complexity are belter off relying morc on informal controls (HOPWOOD, 1974, OTLEY, 1980. OUCHI, 1979). Therefore,

Proposition 1: Project environment tuncenainty is negatively associated with the level of formality in the ISD project controls.

Proposition 2: Project cnvironment complexity is negatively associated with the level of formality in the ISD project controls.

Control literature has noted that the size of an organization is direclly linked to the degrec of formality used in the control mechanisms (BLAU \& SCOTT, 1972, BRUNS \& WATERHOUSE, 1975). Since the ISD project is a part of the IS function, the size of the IS function should also affect the formality of controls used. This would lead us to the next proposition:

Proposition 3: The size of the IS function is positively associated with the level of formality in the ISD project controls.
As mentioned earlier, the linkage betwecn the IS function and the organization will also affect the control process. As the IS function gets more integrated with the rest of the organization, control problems increase (DALTON, 1971. OTLEY, 1980, CHILD, 1972). Compounding of the problem of controls causes greater reliance on formal controls. Also, linkiges between the IS function and the stratcgic function of the organization have bcen proposed to be of various degrees of strenglh (THOMPSON, 1992). Therefore,

Proposition 4: The degrec of linkages betwecn the IS function and the organization stratcgy is positively associated with the level of formality in the ISD projecl controls.

Control litcrature has also identified another organizational environmental factor which may affect the control type used -- financial position of the organization. Organizations in troubled times tend to rely more on formal than informal controls (JAWORSKI, 1988). Thus,

Proposition 5: The financial position of the organization is positively associated with the Icvel of formality in the ISD project controls.

Different organizalions may have different roles for IS. A number of frameworks and cmpirical findings are available in the IS literature to support the facl that the role played by IS in different organizations may vary from highly routinized and stable to highly unstructured and creitive (MCFARLAN \& MCKENNEY, 1983, DAS et al, 1991). In organizations 
where IS is used as a competitive tool, the cmplasis is on innovation in which casc informal controls are more used than formal ones. In others, the IS may take carc of more routinized tasks such as maintcnance of transaction processing systcm, report gencration, ctc. In such cases formal controls are more likely to be used as compared to informal controls. The proposition that the kinds of control employed depend on the nature of task to be performed is well supported in control litcrature (OUCHI \& MAGUIRE, 1975, MARCH \& SIMON, 1958). Thus,

Proposition 6: The level of routinization of the task performed by the IS function is positively associated with the level of formality in the ISD project controls.

As discussed before, the cxlcrnal environment can be broadly characterized by its uncertainty. Both the IS and control litcratures contribute to developing the following propositions. In an exploratory cmpirical survey, Das et al (1991) found that the stability of the enviromment may influence the role of the IS function within an organization. An unstable covironment would contributc to greatcr flexibility within the organization and more informal control stnicture within the IS function. This fact has been supported in control theory (JAWORSKI, 1988). Environmental uncertainty has also been known to affect the kind of controls used (GORDON \& NARAYANAN, 1984). We therefore propose that:

Proposition 7: The uncertainty of the cxternal environment is negatively associated with the level of formality in the
ISD project controls.

Since the purpose of this paper is 10 provide a contingency theory on ISD, we should now focus on explaining how the environment moderates the effect of control mechanisms on the projecl consequences. As cxplained before, the consequences can bc analyzed cither from the individual team members, users or producers perspective. The effect of environment on the consequences implies a certain fit between the control system and the environmental characteristic. The notion of fit has been widely discussed in the IS literature. For the purpose of this study, fit will be loosely defined as the match between the cnvironmental characteristics and the control mechanisms uscd in the ISD projecl. The proposition being made here is that the desirability of the consequences is associated with the degrece of fit between the cnvironmental characteristics and the controls in use within the ISD effort.

The degree of fit will influence the individual team members, producer group and users and other stakeloolder in different way. As discussed carlier, the consequences at the individual level are psychological, role perceptions, belavional and performance. Litcrature in control theory would strongly support a positive association between control and context, and the desirability of individual consequences. Howcver, mosi of the IS literature has ignored consequences of control for the individual project member. Although individual differences have been considered as contingency variables for cxplaining IS performance (FRANZ, 1985, KASPER, 
1985), individual consequences have largely becn ignored. Hence, the proposition conccrning conscquences for individual project member in ISD projects are based on cmpirical and conceptual works done in general control theory not specific to the IS domain (please refer to JAWORSKI (1988) for detailed review and justification of the propositions given below).

Proposition 8: A fit betwecn the environmental context and the controls in use in the ISD project will lead to lower levels of individual team member job tension.

Proposition 9: A fit belween the cnvironmental context and the controls in use in the ISD project will lead to lower levels of individual tcam member role ambiguity and role conflict.

Proposition 10: A fit between the cnvironmental context and the controls in use in the ISD project will lead to lower levels of individual team member dysfunclional bchavior (gaming, smoothing, focusing and iuvalid reporting).

Proposition 11: A fit between the cnvironmental context and the controls in use in the ISD project will lead to higher lcvels of individual tcam member managerial performance.

The notion of fit in IS lais been ty pically viewed as the match between some contingency variables (organizational characteristics) and some characteristic of the information/control systcm (WEILL \& OLSON, 1989). The dependent variable is typically IS performance which, according to our typology, can be studicd from the producers or the users angle.
The consequences of ISD projects at the producers level have been measured in terms of the quality of the product and the production system. All these measures of performance have becn studied under contingency theory in ISD. However, most of the IS literature on contingency approach neglects technical measures from the producers perspective and concentrates on the users/organizational perspective. The following research propositions are intended to fill this gap.

Proposition 12: A fit between the convironmental context and the controls in uSe iin the ISD project will lead to higher lcvels of information product quality.

Proposition 13: A fit between llic environmental context and the controls in usc in the ISD project will lead to higher levels of information systcm quality.

Proposition 14: A fit between the environmental context and the controls in uSc in the ISD project will lead to higher Icvels of process productivity.

In contrast, most of the performance variables studicd under the contingency approach have becn from the uscrs/organizational perspective. The most common performance variables are user salisfaction and systcm usc (GRUDNITSKI, 1984, HOGUE, 1987, MCKEEN. 1983). The contingency variables studied have addressed various aspects of the cnvironment lask, teclunology, stnucture ctc. (please refer to WEILL \& OLSON (1989) for a detailed revicw). On the basis of these empirical findings we propose the following:

Proposition 15: A fit belwecn the cnvironmental context and the controls in 
use in the ISD project will lead to higher levels of user satisfaction.

Proposition 16: A fit betwecn the cnvironmental contcxt and the controls in use in the ISD project will lead to higher levels of system usc.

\section{Conclusion}

The framework discussed in this paper is proposed in the hope of providing a foundation for a contingency-based control framework for ISD projects. However this framework is not without its limitations. By its very nature, a contingency approach is intuitive and hence camot purport to be the best approach. The contextual, contingency variables here provided have intuitive appeal but have been selected in an al hoc manner. The aim was to provide contingency variables which could be as comprehensive and independent as possible. However, we acknowledge that other variables could also mect our requirements.

Though we have presented sixteen research proposition in this paper, by no means they cover all the possible propositions that could be generated from the given framework. Our intention was to highlight only a few broad propositions which, in our personal opinion, were cnough to convey the gist of our discussion. A more comprehensive development of the proposition inventory and empirical testing of them are still necessary to complete and validatc our framcivork. That should also include an cxtcnsion in the control dimension, which was analyzed here only through its formality attributc

Nevertheless. we belicve this framework can be very useful for the IS manager faced with the problem of control in information system development projects. Decisions concerning the use of a particular ISD methodology or the introduction of automation into the ISD process can be guided by the contingencics here proposed if one sees these as control portfolio issues. As recent IS studies have shown (HENDERSON \& LEE, 1992). proper control management of ISD cfforts is critical for the project success and the organization members satisfaction. We hope our framework brings light to this complex issue and opens new avenues of research in the IS field.

\section{References}

AHITUV, N., (1980), 'A systematic approach toward assessing the value of an information system', MIS Quarterly, v. 4,n. 4, December, p. 61-75.

BAILEY, J. E. \& PEARSON, S. W., (1983), 'Dcvelopment of a 1001 for measuring and analyzing computer user Satisfaction', Management Science, v. 29, n. 5. May, p. 530-545

BAILYN, L. (1984), Autonomy in the Indusirial R\&D Lab, MIT Press, Cambridgc. MA.

BASILI. V., (1984). 'Presentation to 
IEEE Working Group for Software Productivity Metrics,' Nashua, NH, Sept.

BENJAMIN,C., (1982), 'Information technology in the 1990s: a long range planning scenario', MIS Quarterly, v. 6, n. 2, p. $11-31$.

BLAU, P., \& SCOTT, W. R., (1972), Formal Organizations, San Francisco, Chandler Publishing.

BOLAND, JR., R. J., (1978), 'The process and product of system design', Management Scicnce, v. 24, n. 9, p. 887-898.

BRUNS, JR., W., WATERHOUSE, J. H., (1975), 'Budgetary control and organizational structure', Journal of Accounting Rescarch, v. 13, Autumn, p. 177-202.

BURNS, R. N., DENNIS, A. R., (1985), 'Selccting the appropriatc application development methodology', DataBase, v. 17, n. 1, p. 19-23.

CARTER, N. M, (1984), 'Computcrization as a predominatc technology: its influence on the structure of newspaper organizalions', Academy of Management Joumal, v. 27, p. 247-270.

CHILD, J., (1972), 'Organizational structure and stratcgics of control: a replication of the Aston sludy', Adminstrative Science Quarterly, v. 17, Junc. p. 16.3-177.

DALTON. G. W., (1971), 'Motivation and control in organizations', in Motivation and control in organizations, G. W. Dalton and P. R. Lawrence (cds.), Homewood, IL, Richard D. Invin, Inc., p. 1-35.

DAS, S. R., ZAHRA, S. A., WARKENTIN, M. E., (1991), 'Integrating the content and process of strategic MIS planning with competitive strategy', Decision Sciences, v. 22, p. 953-984.

DELONE,W. H. AND MCLEAN, E. R., (1992), 'Information systcms success: the quest for the dependent variable', Information Systems Rescarch, v. 3, n. 1, March, p. 60-95.

DE BRABANDER, B., THIERS, G., (1984). 'Successful information system development in relation to situational factors which affect effective communication between MIS-users and EDP-specialists', Management Science, v. 30, n. 2, p. 134-149.

EDSTROM, A., (1977), 'Uscr influence and the success of MIS projects', Human Relations, v. 30, p. 589-606.

EISENHARDT, K. M., (1985), 'Control: organizational cconomic approaches', Management Science, v. 31, n. 2 , p. $132-149$.

ELAM, J. J. AND WALZ. D.. (1988), 'A sludy of conflict in group design actvitics: implications for computer supported cooperalive work environments", in B.R. Konsynski (cd.), Proccedings of the 2 ist Annual Hawaiin Intcrnational Conference on System 
Scicnces, v. 3, p. 247-254.

EMERY, J. C., (1971), 'Cost/benefit analysis of information systems', SMIS Workshop Report, n. I, The socicly for Management Information Systems, Chicago, IL.

FLAMHOLTZ, E. G., DAS, T. K. AND TSUI, A. S., (1985), 'Toward an integrative framework of organizational control', Accounting Organizations and Society, v. 10. n. 1, p. 35-50.

FRANZ, C. R., (1985), 'User leadership in the systems development life cycle: a contingency model', Journal of MIS, v. 2,n. 2, Fall, p. 5-25.

GORDON, L. A., NARAYANAN, V. K., (1984) 'Managcment accounting systems, perceived cnvironmental uncertainty and organization structure: an cmpirical investigation', Accounting, Organizations and Socicty, v. 9,n. 1, p. $33-47$.

GORRY, G. A., SCOTT-MORTON, M. S., (1971), 'A frumework for management information systems', Sloan Management Review, v. 13, n. 1, Fall, p. 55-70.

GRADY, R. B. AND CASWELL, D. L., (1987), Software metrics: establishing a company-wide program, Prentice-Hall, EC, NJ.

GRUDNITSKI, G., (1984), 'Eliciting decision-maker's infromation requirements', Joumal of MIS, v. I,n. I, Summer, p. 18-32.
HAREL, E. AND MCLEAN, E., (1985), 'The effects of using a non-procedural computer language on programmer productivity', MIS Quarterly, v. 9,n. 2, June, p. 109-120.

HENDERSON, J. C.AND LEE, S., (1992), 'Managing I/S design teams: a control theories perspective', Management Science, v. 38, n. 6, June, p. 757-777.

HIRSCHHEIM, R., KLEIN, H.. AND NEWMAN. M., (1987), 'A social action perspective of information systems development', in J. Degross and C. Kriebel (cds.), Procecdings of the Eighth International Conference on Information Systems, Pittsburgh, PA, p. 45-56.

HOGUE, J. T., (1987), 'A framework for the cxamination of management involvement in decision suppont systems, Journal of MIS, v. 4, n. 1, Summer.

HOPWOOD, A., (1974), Accounting and Human Behavior, London: Hay market Publishing Lid.

IVES, B. \& LEARMONTH, G., (1984), 'The information system as a competitive weapon'. Communications of the ACM, v. 27, n. 12. December, p. 1193-1201.

IVES, B. AND OLSON, M. H., (1984), 'User involvement and MIS success: a revicw of research', Management Science, v. 30, n. 5, May, p. 586-603.

JAWORSKI, B. J., (1988), 'Toward a theory of marketing control: cuvironmental context, control types. and 
consequences',JournalofMarketing,v.25, July, p. 23-39.

JENKINS, A.,M., (1985), 'Prototyping: A methodology for the design and development of application systems', Spectrum, v2,n2.

JONES, C., (1987), 'Mcasuring programming quality and productivity', IBM System, v. 17, n. 1, p. 39-63.

KASPER, G. M., (1985), 'The effect of user-developed DSS applications on forecasting decision-making performance in an cxpcrimental setting', Journal of MIS, v. 2 ,n. 2 , Fall, p. 26-39.

KEMERER, C. F., (1989), 'An agenda for research in the managerial cvaluation of computer-aided software enginecring (CASE) tool impacts', Proceedings of the 22nd Annual Hawain Intcrnational Conference on Systems Science, Kailua-Kona, HI, January 3-6, p. 219-228.

KEMERER, C. F. AND SOSA, G. L., (1990), 'Systems development risks in stratcgic information systems', Center for Information Systems Rescarch Working Paper \#206, MIT, Cambridge, MA, May.

KLATZKY, S. R., (1970), 'Size and the locus of decision making: the cascade effect', Joumal of Business Automation, $v$. 43, p. 141-151.

KOLODZIEJ, S., (1986), 'Gaining control of maintenance', Computenvorld Focus, Fcbruary 19, p.30-36.

LARCKER, D. F., LESSIG, V. P.,
(1980), 'Perceived usefulness of information: a psychometric cxamination', Decision Sciences, v. 11, n. 1, January, p. 121-134.

\section{*LAWLER (1976)}

LOUADI, M. E., POLLALIS, Y. A., TENG, J. T. C., (1991), 'Sclccting a systcms development methodology: a contingency framework'; Information Resources Management Journal, v. 4,n. 1, Winter, p. 11-19.

LOUIS, F., (1992), 'The rules of projed management', Information Systems Managcment, v. 9, n. 3, Summer, p. 71-74.

LUCAS, JR., H. C., (1975), 'Performance and the use of an information system', Management Scicnce, v. 21, n. 8, p. $908-919$.

MARCH, J. G., SIMON, H., (1958), Organizations, John Wilcy and Sons, NY.

MASON, R. O., (1978), 'Mcasuring information output: a communication systcms approach', Information and Management, v. 1, n. 5, October, p. 219-234.

MCCOMB, D., SMITH, J. Y., (1991), 'Systcm project failure: the heuristics of risk', Journal of Information Systems Management, Winter, p. 25-34.

MCFARLAN, F. W. \& MCKENNEY, J. L., Corporatc Information Systems Managcment: The issues facing senior cxeculives, Homcwood, IL: Richard D. Invill. 
MCKEEN, J. D., (1983), 'Successful development strategics for business apllication systems', MIS Quanerly, v. 7, n. 3, September, p. 47-66.

\section{*MERCHANT (1985)}

MILLS, H. D., (1971), 'Chief programmer teams: principles and proceduers', IBM Report, FSC 71-5108, IBM Federal Systems Division, Gathersburg. MD

MUNRO, M. C.. DAVIS, G. B., (1977), 'Determining management information necds: a comparison of methods', MIS Quartcrly, v. 1, n. 2, Junc, p. 55-67.

OTLEY, D., (1980), 'The contingency theory of management accounting: achievement and prognosis', Accounting, Organizations and Socicly. v. 5. p. 413-428.

OUCHI, W.G., (1979), 'A conceptual framework for the design of organization control mechanisms', Management Science, v. 25, n. 9. p. 833-848.

OUCHI, W. G., (1977), 'The relationship betwecn organizational structure and organizational control', Administrative Science Quarterly,

OUCHI. W. G. MAGUIRE, M. A., (1975), 'Organizational control: Two functions', Administrative Science Quarterly, v. 20, 11. 4. p. 55)-569.

PARK, C. W.. AND ZALTMAN, G., (1987), The management of markets, NY,
Dresden press.

ROBEY. D., AND FARROW, D. (1982), 'User involvement in information systems development: a conflict model and empirical test', Management Science, v. 28, n. 1, p. 73-85.

SHANNON, C. E., WEAVER, W., (1949), The mathematical thcory of communication, University of Illinois Press, Urbana, IL.

SWANSON, E. B., (1974), 'Management information systems: appreciation and involvement'. Management Science, v. 21, n. 2, October, p. $178-188$.

THOMPSON, T. S. H., (1992) 'An cmpirical study of linkages between business planning and information systems planning', Disscrtation Proposal. University of Piltsburgh, Scplember.

VITALE, M., IVES, B., BEATH, C., (1986), 'Identifying strategic information systcms: finding a process or building an organization', Procecdings of the Seventh International Conference on Information Sysicms, p. 256-276.

WATERHOUSE, J. H., TIESSEN, P., (1978), 'A contingency framework for management accounting systems rescarch', Accounting. Organizations and Sociely, $v$. 3. p. 65-76.

WEILL, P., OLSON, M., (1989), 'An assessment of the contingency theory of management information Systems'. Journal of Management Information 
Sysicms, v. 6, n. 1, Summer, p. 59-85.

WEINBERG, G., (1971). The psychology of computer programming, Van Rostrand Rcinhold, NY.
*WOODWARD (1970)

ZMUD, R. W., (1979), 'Individual differences and MIS success: a revicw of the cmpirical literature', Management Sciencc, v. 25, n. 10. October, p. 966-979.

\section{Acknowledgments}

Paulo R Flot is a felow of CNP -Conisellio Nacional de Deservolvimento Cientifico c Tecuologico, Brazil Ranit Tinakar would like to thank lis wife Dee for lier love and stipport. 